\title{
Properties of cellulose nanofibre networks prepared from never-dried and dried paper mill sludge
}

\author{
Cynthia Adu ${ }^{\mathrm{a}}$, Linn Berglund ${ }^{\mathrm{b}}$, Kristiina Oksman ${ }^{\mathrm{b}}$, Stephen J. Eichhorn ${ }^{\mathrm{c}}$, Mark Jolly ${ }^{\mathrm{a}}$, \\ Chenchen $\mathrm{Zhu}^{\mathrm{c}}$ \\ ${ }^{a}$ Manufacturing and Materials Department, Cranfield University, MK43 OAL, UK \\ ${ }^{b}$ Division of Materials Science, Luleå University of Technology, Luleå SE 97187, Sweden \\ ${ }^{\mathrm{c} B r i s t o l}$ Composites Institute (ACCIS), Queens Building, School of Engineering, Bristol University, BS8 1TR, \\ $U K$
}

\begin{abstract}
Paper mills yield large volumes of sludge materials which pose an environmental and economic challenge for disposal, despite the fact that they could be a valuable source for cellulose nanofibres (CNF) production. The aim of the study was to evaluate the production process and properties of CNF prepared by mechanical fibrillation of never-dried and dried paper mill sludge (PMS). Atomic force microscopy (AFM) showed that average diameters for both never-dried and dried paper sludge nanofibres (PSNF) were less than $50 \mathrm{~nm}$. The never-dried and dried sludge nanofibres showed no statistical significant difference ( $\mathrm{p}>0.05$ ) in strength $\sim 92 \mathrm{MPa}$, and $\sim 85 \mathrm{MPa}$ and modulus $\sim 11 \mathrm{GPa}$ and $\sim 10 \mathrm{GPa}$. The study concludes that paper mill sludge can be used in a dried state for CNF production to reduce transportation and storage challenges posed on industrial scale.
\end{abstract}

\section{Introduction}

Biopolymeric materials derived from environmentally friendly sources are gradually becoming competitive with traditional polymers derived from non-renewable sources (Pickering et al., 2015; Montoya et al., 2014; Thakur, 2014). Agricultural crops have been suggested as a raw material to produce biodegradable polymers. However, in the present era of limited resources, there is a competition of using land to grow lignocellulose biomass instead of food crops (Valentine et al., 2012). The circular economy principles promote the optimisation of resources by extracting valuable biochemical feedstocks from existing industrial processes. For example, agro-industry waste such as sugar cane bagasse, carrot residue and brewery waste has been used to produce nanocellulose (Berglund et al., 2016; Golbaghi et al., 2017; Nuruddin et al., 2016).

Ideally, nanocellulose is produced from cellulose sources such as plants, wood, tunicate and algae by the breakdown of their structure, either by chemical and/or mechanical means to produce cellulose nanofibres (CNFs), or by acid hydrolysis to form cellulose nanocrystals (CNCs) (Eichhorn et al., 2010; Hsieh et al., 2008; Moon et al., 2011). These cellulose nanofibres are characterised by their high aspect ratio, high stiffness and crystallinity. The elastic modulus of the crystalline regions of 
cellulose was first determined from the deformation of bleached ramie fibres resulting in a value of $137 \mathrm{GPa}$ for the crystal modulus (Sakurada et al., 1962), further research on modulus of cellulose reported values ranging from 100-140 GPa (Northolt et al., 2005; Sturcova et al., 2005). The specific mechanical properties, when divided by the density of cellulose $\left(\sim 1.5 \mathrm{~g} \mathrm{~cm}^{-3}\right)$, are comparable to engineering materials such as steel, glass or aluminium. Hence, they can be used in high value applications such as automotive, packaging materials, biomedical applications, sensors and membranes (Trache et al., 2017). However, the application of CNF in industry is limited by availability as the mass production of nanocellulose is hindered mainly due to its high production costs (Delgado-Aguilar et al., 2015; Oksman et al., 2016).

Nevertheless, to reduce cost and scale up production of nanocellulose, Paper mill sludge (PMS). has been proposed as a cheap and sustainable raw material for producing CNFs. PMS is an industrial effluent of paper mills produced in large volumes; one million tonnes is produced in the UK alone. Disposal of PMS poses an economic challenge of $£ 82.60 /$ tonne and risks potential release of 2.60 tonnes of $\mathrm{CO}_{2}$ if not managed to environmental disposal standards (Adu and Jolly, 2017; Faubert et al., 2016; Likon et al., 2011). Despite being rich in cellulose, PMS is currently used in low value applications for land spreading (Monte et al., 2009; Phillips et al., 1997) and animal bedding (Villagrá et al., 2011). Moreover, using PMS means no chemical pre-treatment is required to dissolve lignin unlike other biomass residues, and it can be obtained free of charge from the mill thereby reducing cost. However, a foreseeable industrial challenge of processing large quantities of PMS into cellulose nanofibres is the high chance of microbial activity during storage and transportation as the sludge is often obtained never-dried/wet from the paper mills with up to $80 \%$ moisture content (Ghribi et al., 2016).

In the literature, never-dried sludge has been used to produce CNF with widths 5-30 nm by high pressure defibrillation at $138 \mathrm{kPa}$ and chemical bleaching with $\mathrm{NaOH}$ (Leão et al., 2012). Never-dried sludge from a dissolving cellulose mill was also used to produce CNF $(<100 \mathrm{~nm})$ by mechanical fibrillation (Jonoobi et al., 2012). The use of never-dried/wet cellulose material is highly desirable for CNF production in comparison to once dried material. This is because of the phenomenon known as hornification, which promotes an irreversible bonding between fibrils thus leading to reduced mechanical properties in dried pulp (García et al., 2002; Spinu et al., 2011). However, the use of dried sludge provides an advantage to prevent bacterial degradation, reduces transportation costs and storage challenges. The use of dried sludge as opposed to never-dried sludge for producing CNF has not been investigated in the literature. Thus, this study draws a comparative evaluation between the production process and properties of CNFs obtained from never-dried and dried paper mill sludge. The nanofibres obtained from the sludge are referred to as paper sludge nanofibres (PSNF); neverdried $\left(\mathrm{PSNF}_{\mathrm{ND}}\right)$ and dried $\left(\mathrm{PSNF}_{\mathrm{D}}\right)$. 


\section{Materials and methods}

\subsection{Material}

Never-dried sludge was obtained from a paper mill producing kitchen towel rolls with hardwood and softwood pulps such as eucalyptus or pine. One batch of the same sludge was also dried for $24 \mathrm{hrs}$ in an oven and stored for 3 months. The paper mill yields 4000 tonnes of PMS annually, which is used for agricultural land spreading or animal bedding.

\subsection{Chemical composition of sludge}

The ash content of the sludge sample was determined using TAPPI 211 standards ash in wood, pulp and paperboard at $525{ }^{\circ} \mathrm{C}$ (TAPPI, 2004). Hemicellulose, cellulose and lignin were tested using direct chemical methods (Moubasher et al., 1982). Ethanol was used to treat $2 \mathrm{~g}$ of PMS, two parts of $1 \mathrm{~g}$ each. Part 1 is dry weighed as fraction A, while part 2, namely fraction $\mathrm{B}$, was treated with $24 \%$ $\mathrm{KOH}$. After dry weighing, fraction B was further treated with $72 \% \mathrm{H}_{2} \mathrm{SO}_{4}$ and refluxed with $10 \%$ $\mathrm{H}_{2} \mathrm{SO}_{4}$; this was labelled as fraction $\mathrm{C}$. After each stage, all fractions were washed thoroughly in distilled water and dried overnight at $80^{\circ} \mathrm{C}$ before weighing. Deductions of the weighed fractions (A, $\mathrm{B}$ and $\mathrm{C}$ ) were used to calculate the organic composition of the sludge. The cellulose content is given by fraction B-C, hemicellulose (A-B) and lignin (C itself). The morphology of the PMS was studied using Scanning Electron Microscopy (SEM) JSM-6490LV, JEOL (Japan) with a $12 \mathrm{kV}$ acceleration voltage, in back-scatter electron (BSE) detector mode, to obtain a chemical analysis of inorganic minerals in the sample. Oxford instruments Aztec ${ }^{\mathrm{TM}}$ EDS element mapping software was used to process the data. Thermogravimetric analysis (TGA) was also used to confirm the organic composition of the sludge, and the presence of inorganic material (Lin et al., 2015; Yang et al., 2006). TGA of PMS was determined in accordance with the ASTM-E1131-03 standard test method for compositional analysis of thermogravimetry using a Mettler Toledo TGA/DSC analyser. TGA/DSC was used to measure the mass change of the specimen in an increasing temperature range from 25 $600{ }^{\circ} \mathrm{C}$, at a heating rate of $10^{\circ} \mathrm{C} / \mathrm{min}$.

\subsection{Processing of cellulose nanofibres from never-dried and dried PMS}

Never-dried and dried PMS was fibrillated using a super mass collider MKCA6-3 (Masuko Sangyo Co, Japan), at a consistency of $2 \mathrm{wt} . \%$. Prior to the ultrafine grinding process, the suspension was dispersed in deionised water using a shear mixer Silverson L4RT (Silverson Machine Ltd. England). The dried PMS required a $24 \mathrm{hrs}$ soaking before dispersion in deionised water. The 
grinding stones used were coarse silicon carbide $(\mathrm{SiC})$ with several grooves on the surface. Centrifugal forces from the repeated cyclic pressure and shearing stress cause the microfibre suspension to move outwards from the grooves. The forces on the fibre suspension result in the defibrillation of the fibres by setting the grinding stones in contact mode after the initial feeding and gradually adjusting them to $-90 \mu \mathrm{m}$. The rotor speed was set to $1500 \mathrm{rpm}$. The energy consumption for the mechanical separation was based on the direct measurement of power in Watts, using a power meter produced by Carlo Gavazzi (model, EM24 DIN, Italy). The energy consumption for the grinding process is converted to $\mathrm{kWh}$ per $\mathrm{kg}$ of the nanofibres' dry weight, calculated using the equation.

$$
\text { Energy }(J)=\text { power }(W) \times \text { time }(h)
$$

To assess the degree of fibrillation, viscosity measurements were carried out using a Vibro Viscometer SV-10, (A\&D Company, Ltd., Japan). The details of the fibrillation process are shown in Fig.1. The viscosity measurements were conducted at room temperature $\left(22.5^{\circ} \mathrm{C}\right)$ based on testing three samples each collected from different intervals during the fibrillation process until reaching a plateau in the viscosity. The plateau viscosity was reached after a 150 min processing time.

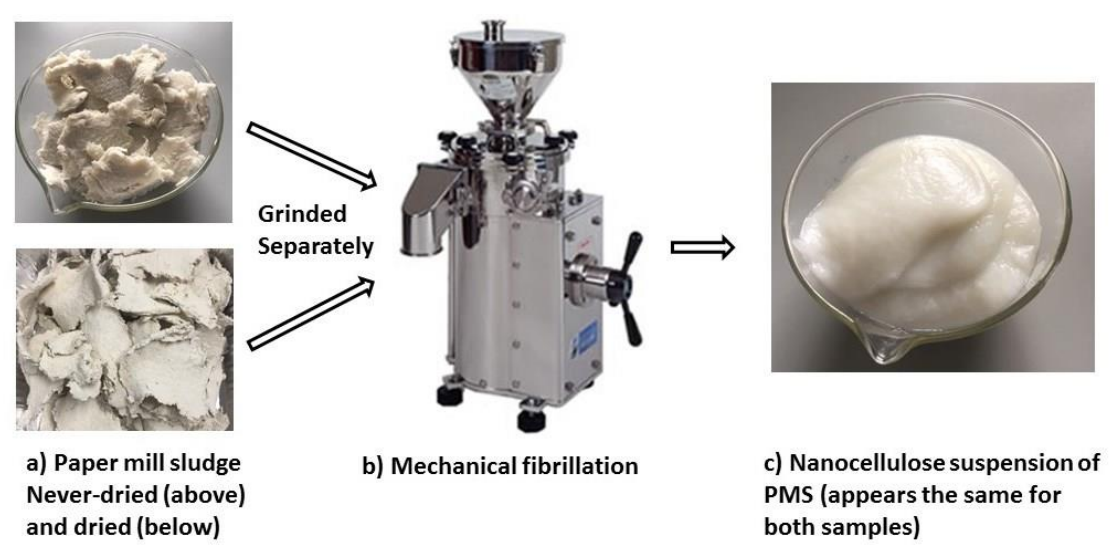

Fig.1. Schematic of the preparation steps for a cellulose nanofibre suspension produced from paper mill sludge with mechanical ultrafine grinding (suspension appears the same for both sample).

The microstructure of both materials was also studied during fibrillation at different time intervals using polarised microscopy (Nikon Eclipse LV100N POL, Japan) and the imaging software NISElements D 4.30. The PMS fibre dimensions were measured with a Metso FS5 fibre image analyser (Metso Automation, Finland) in accordance with the ISO 16065-2:2007 determination of fibre length by automated optical analysis, using unpolarised light. 


\subsection{Preparation of nanofibres networks}

Nanofibre networks were prepared by using the CNF suspension to fabricate nanopaper sheets. The CNF suspension was adjusted to $0.2 \mathrm{wt} . \%$, after which it was dispersed at $10,000 \mathrm{rpm}$ for $10 \mathrm{~min}$, using a shear mixer, IKA T25, UltraTurrax, (IKA-Werke GmbH \& Co., Germany). The dispersed CNF solution was de-gassed and vacuum filtration undertaken with a $0.45 \mu \mathrm{m}$ and $125 \mathrm{~mm}$ diameter membrane filter. The gel formed was placed between two metal plates lined with a stainless-steel mesh and hot pressed at $110{ }^{\circ} \mathrm{C}$ and $1.1 \mathrm{MPa}$ for $30 \mathrm{~min}$ using Fortune presses, LP300, (Fontijne Grotnes, The Netherlands). Under the same conditions, but for 10 mins, a surface finishing was carried out by replacing the mesh lining with polyester films.

\subsection{Characterisation of paper sludge nanofibre}

The PSNFs were characterised to obtain fibre dimensions and mechanical properties of sheets of the material. Atomic force microscopy (AFM) was carried out using a digital instruments Dimension 3100 AFM equipped with Veeco Nanoscope IV controller (Bruker, UK). AFM was performed in tapping mode at the resonance frequency of the cantilever with a scan rate of $0.4 \mathrm{~Hz}$ and a scan size of $8.8 \mu \mathrm{m}$. Samples for AFM were prepared by depositing a dilute drop of $0.01 \mathrm{wt} . \%$ fibrillated sludge fibres on a freshly cleaved mica plate, and allowing this to dry at room temperature. The fibre dimensions were measure from the AFM using Veeco Nanoscope analysis software and images were collected from independent scans. AFM measures the diameter of the fibres by scanning the tip across the surface of the specimen with a scan size of $30 \mu \mathrm{m}$. Height measurements were taken from individual fibres protruding out of a network within four different scan areas with 100 fibres measured in total. Areas with agglomerated fibres were not considered in the measurement analysis. X-ray diffraction analysis of the nanopaper was conducted using a Bruker D8 ADVANCE X-ray diffractometer (Bruker Co., Germany), multiple nanopaper samples were mounted and exposed to $\mathrm{Cu}$ $\mathrm{K} \alpha$ radiation with a step size of $0.03^{\circ}$ at $2 \theta=5-40^{\circ}$. The diffraction pattern for never-dried and dried PSNF were used to calculate crystallinity index ( $\mathrm{Cr} I$ ) based on Segal's method (equation 2) (Segal et al., 1958)

$$
\operatorname{CrI}(\%)=\frac{I_{\text {total }}-I_{\text {am }}}{I_{\text {total }}}
$$


where $I_{\text {total }}$ is calculated from the maximum scattered intensity from the main peak (110) and $I_{a m}$ is the minimum scattered intensity between the main and secondary peaks for cellulose. A peak fitting method (equation 3) has also been used to calculate $\mathrm{Crl}$ as Segal's method has been known to underestimate the amorphous fraction. This method deconvolutes each peak using a Gaussian function after which the amorphous region is subtracted and the $\mathrm{CrI}$ is calculated by dividing the total scattered intensity area of each crystalline peak by the total scattered intensity area of the diffraction spectra (Park et al., 2010).

$$
\operatorname{CrI}(\%)=\frac{A_{\text {crystalline }}}{A_{\text {total }}}
$$

The transmittance of a PSNF suspension $(0.2 \mathrm{wt} . \%)$ was measured using a UV-VIS-NIR extended range FLAME-S-XR1 spectrophotometer (Ocean Optics, UK) set in the range of 200-1000 nm with distilled water used as a reference. The opacity of the nanopaper was measured using a Elrepho 070 spectrometer (Lorentzen and Wettre, Sweden). Tensile tests were conducted on the nanopaper samples using a universal testing machine manufactured by Shimatzu AG-X (Japan) using a $1 \mathrm{kN}$ load cell, and an extension rate of $2 \mathrm{~mm} / \mathrm{min}$ and a $20 \mathrm{~mm}$ gauge length between the clamps. All samples were conditioned in an environmental cabinet, which maintained $50 \%$ relative humidity (RH) and $23{ }^{\circ} \mathrm{C}, 24 \mathrm{hrs}$ before testing. The reported results were obtained from 8 test specimens that failed in the middle of the gauge length. Tensile strength was calculated from the force and cross-sectional area of the paper. Tensile index was calculated in accordance with (TAPPI, 2006) standards which considers the weight per unit area of the paper $\left(\mathrm{g} / \mathrm{m}^{2}\right)$ instead of the thickness. Results of tensile index for mechanical fibrillated CNF have been reported by Yousefi et al. (2013) as $87.7 \mathrm{Nm} / \mathrm{g}$.

\section{Results and discussions}

\subsection{Chemical composition and thermal analysis of sludge}

A summary of the PMS chemical composition is illustrated in Table 1, The composition results of both never-dried and dried samples of PMS are the same as they were collected from the same batch.

\section{Table 1}

Chemical composition of paper sludge.

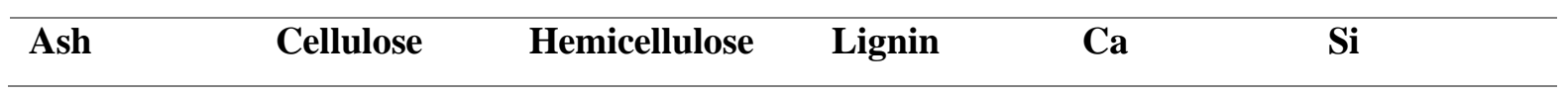




\begin{tabular}{llllll}
\hline $1.3 \%$ & $74 \%$ & 2.6 & 1.3 & 2.4 & $<1 \%$
\end{tabular}

The EDX spectrum in Figure 2 (left) shows that the major component of the sludge is organic $(\mathrm{C}$, O) although trace elements of magnesium $(\mathrm{Mg})$, aluminium $(\mathrm{Al})$, Silicon $(\mathrm{Si})$ and Calcium $(\mathrm{Ca})$ are present. These inorganic components may come from fillers, sizing agents, possible contaminants and trace elements present in the waste-water. The TGA analysis in Figure $2 b$ is as expected for the sludge. The organic content of PMS, which is mainly cellulose and hemicellulose, thermally decomposes at $\sim 300^{\circ} \mathrm{C}$, whilst the mineral fillers remain thermally stable after $500{ }^{\circ} \mathrm{C}$.
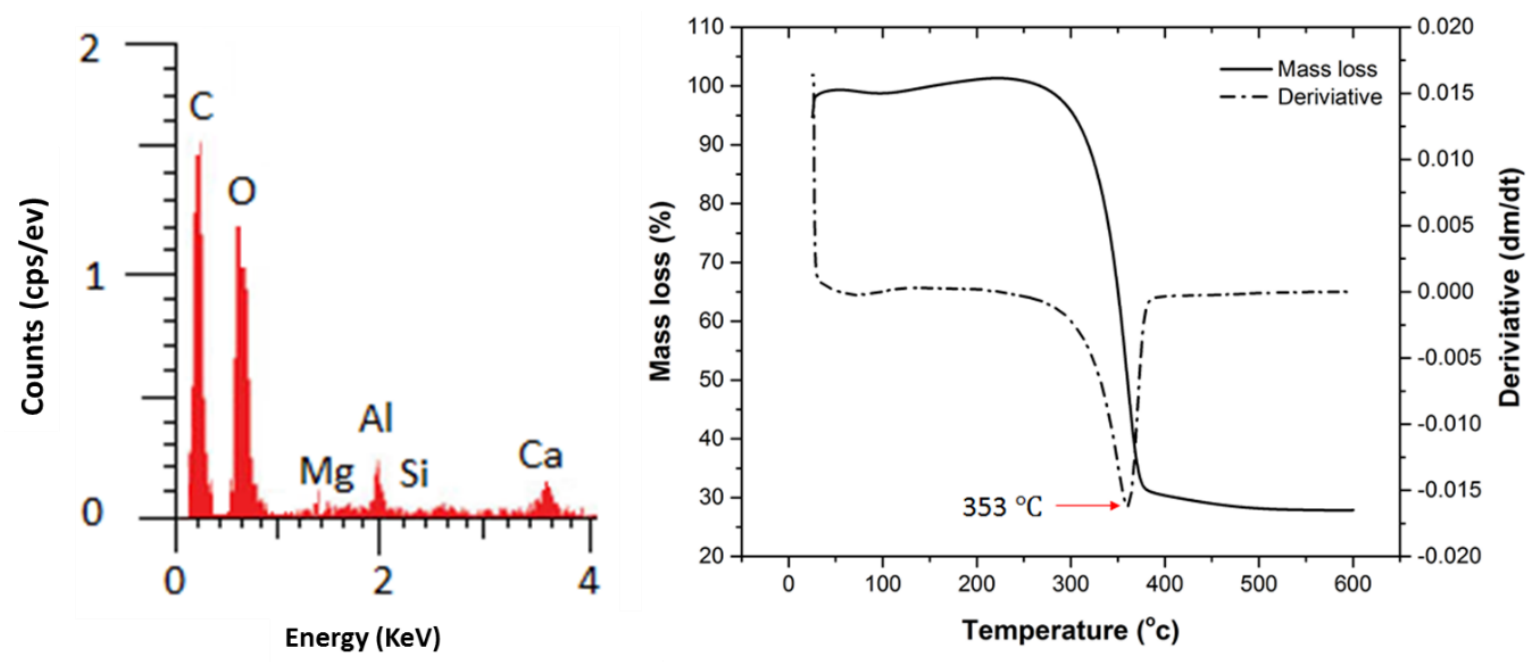

Fig.2. A typical EDX spectrum showing peaks of elements contained in a PMS sample (left), themogravimetric traces and a deriviative curve (dotted line) of the PMS showing the highest degradation peak at $353{ }^{\circ} \mathrm{C}$ attributed to the thermal decomposition of cellulose (right)

\subsection{Microscopy of nanofibres}

Polarised light micrographs of the paper sludge showed changes in the fibre size at different time intervals during fibrillation (Fig. 3). After 45 min fibrilation the dried PMS fibre showed no obvious reduction in fibre size compared to the never-dried PMS at $45 \mathrm{~min}$. The microscopy image for the dried sludge presented a few large fibres circled in red at $120 \mathrm{~min}$ and $150 \mathrm{~min}$. 

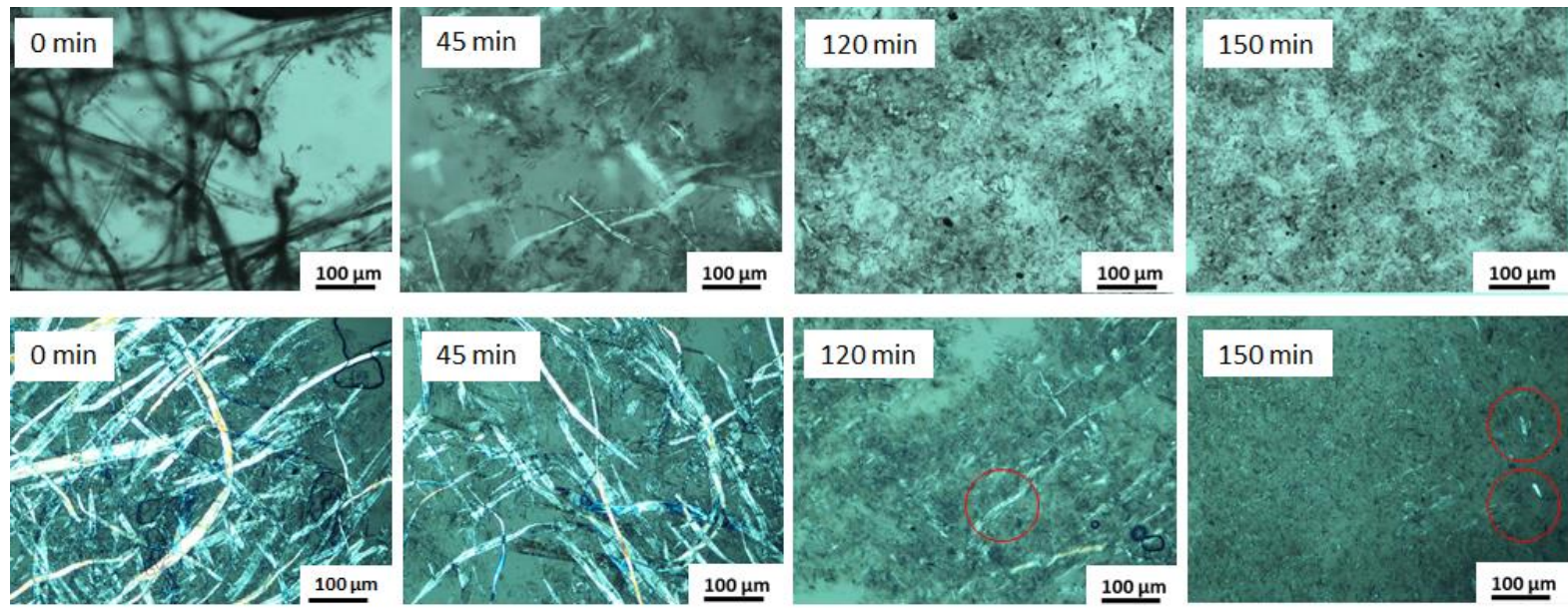

Fig.3. Typical polarized microscopy images of PMS fibres at fibrillation time intervals showing a reduction in fibre/nanofibre widths for never-dried sludge (above) and dried sludge (below).

During the mechanical grinding process, an increase in viscoity gives an indication of the degree of fibrilation. The viscocity and energy consumption of never-dried and dried PMS at differing intervals of fibrillation is shown in Fig.4.
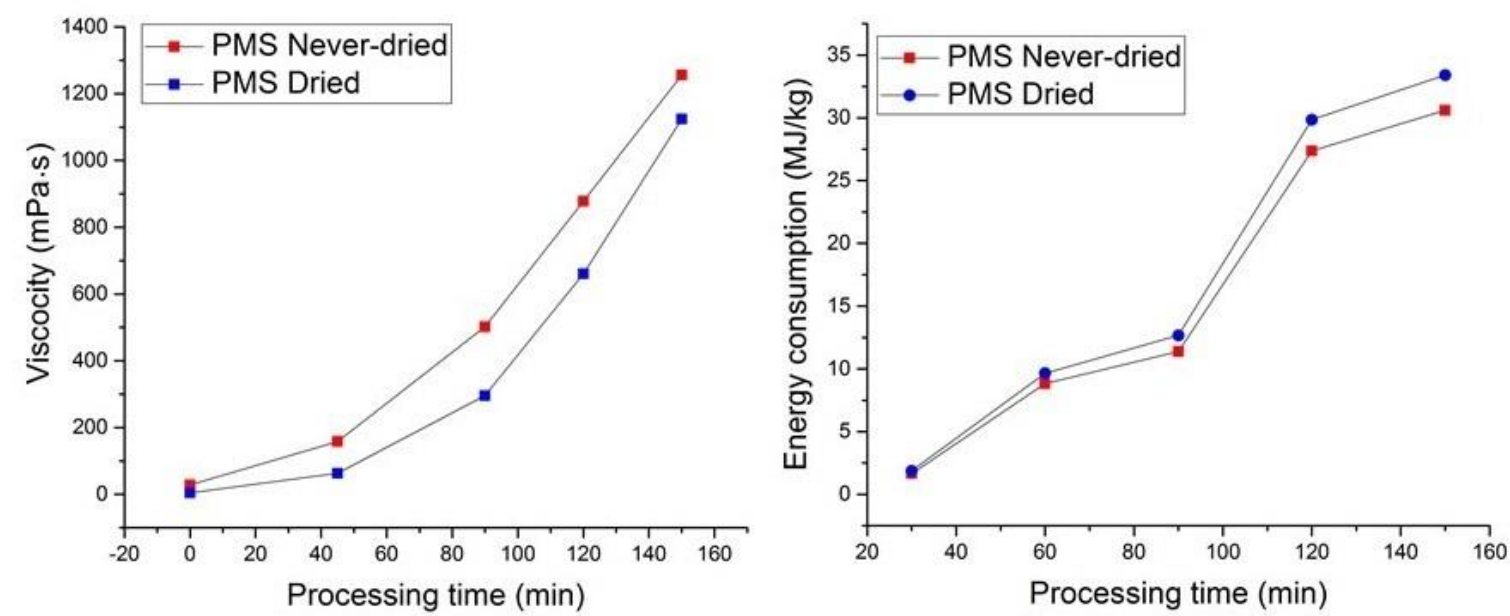

Fig.4. Increases in viscosity (left) and increase in energy consumption (right) as a function of processing time for never-dried and dried PMS (to convert MJ/kg to $\mathrm{kWh} / \mathrm{kg}$ divide by 3.6).

The starting viscocity for the never-dried PMS (5 mPa.s) was lower than the dried PMS (28 mPa.s). Both PMS showed an exponetial increase in viscocity until reaching equilibrium. The never-dried PMS showed a higher viscocity (1256 mPa.s) than the dried PMS (1124 mPa.s). The energy 
consumption of never-dried PMS was $30.6 \mathrm{MJ} / \mathrm{kg}$ whereas the dried material consumed $33.5 \mathrm{MJ} / \mathrm{kg}$ of energy due to a higher rotor speed required to process it.

\subsection{AFM imaging of paper sludge nanofibres}

Fig. 5. shows the morphology and width distributions of the paper sludge nanofibres (PSNFs). The average nanofibre diameter for $\mathrm{PSNF}_{\mathrm{ND}}$ was found to be $34 \pm 15 \mathrm{~nm}$, with more than $60 \%$ of these values being between $20-50 \mathrm{~nm}$ whilst the $\mathrm{PSNF}_{\mathrm{D}}$ showed comparable fibre width of $41 \pm 13 \mathrm{~nm}$.
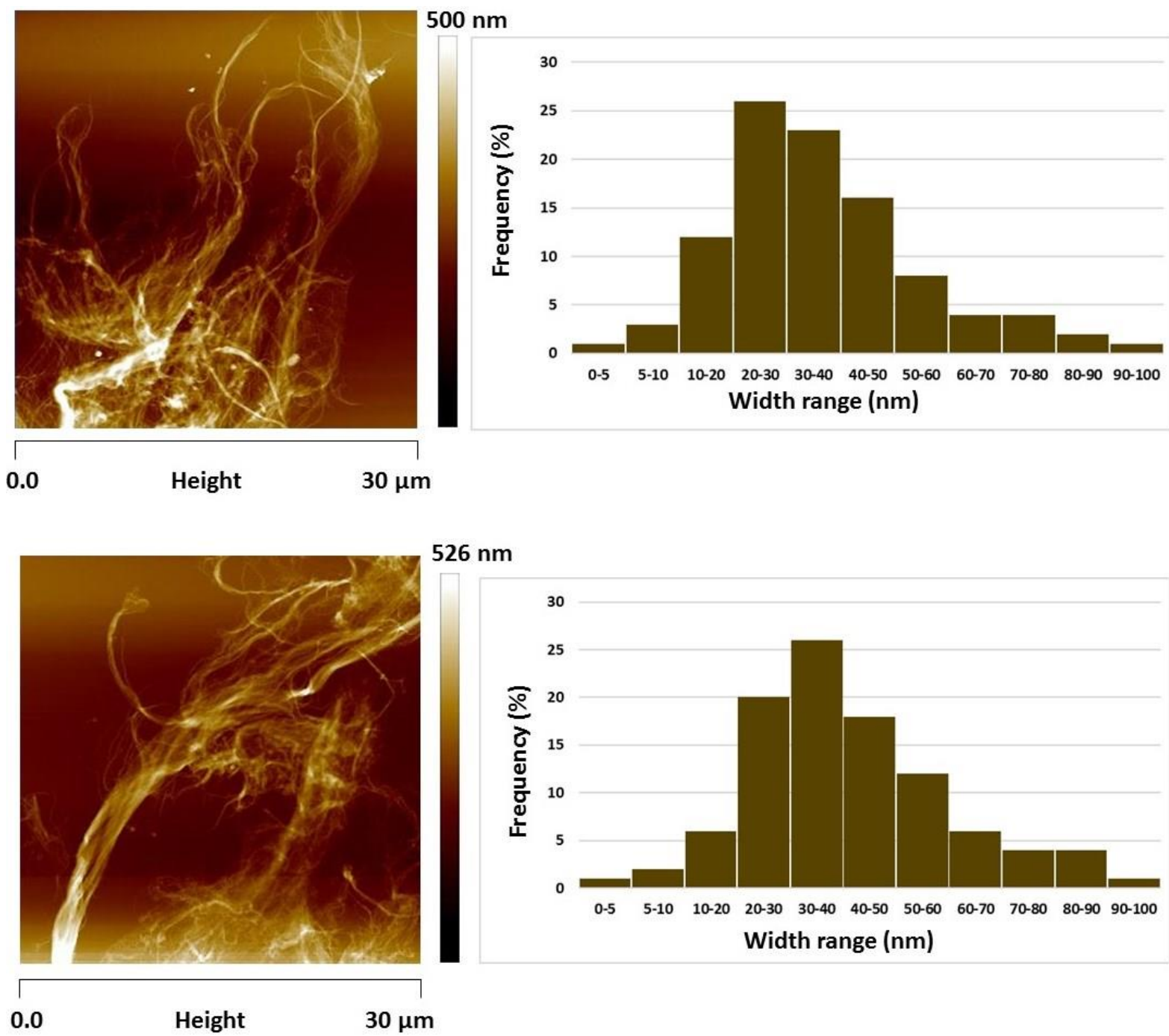

Fig.5. AFM height of paper sludge nanofibres (PSNFs) and width distribution of PSNF; $\mathrm{PSNF}_{\mathrm{ND}}$ (above) and $\mathrm{PSNF}_{\mathrm{D}}$ (below). 


\subsection{Powder X-ray Diffraction (XRD) analysis of sludge nanofibres}

The X-ray diffraction patterns for both $\mathrm{PSNF}_{\mathrm{ND}}$ and $\mathrm{PSNF}_{\mathrm{D}}$ exhibited a number of intensities within the $2 \theta$ angle range (Fig.6 left). The intensities labelled (a), (e) and (g) are attributed to crystalline talc $(\mathrm{MgSi} 4 \mathrm{O} 10(\mathrm{OH}) 2)$, which is a common filler used in the paper industry; the presence of this compound can also be confirmed by the observation of these elements in the EDX spectrum. Similar peaks have also been identified in XRD of paper sludge (Frías et al., 2015) and talc used as a filler in polylactic acid (PLA) exhibited the same intensities (Buzarovska et al., 2016).
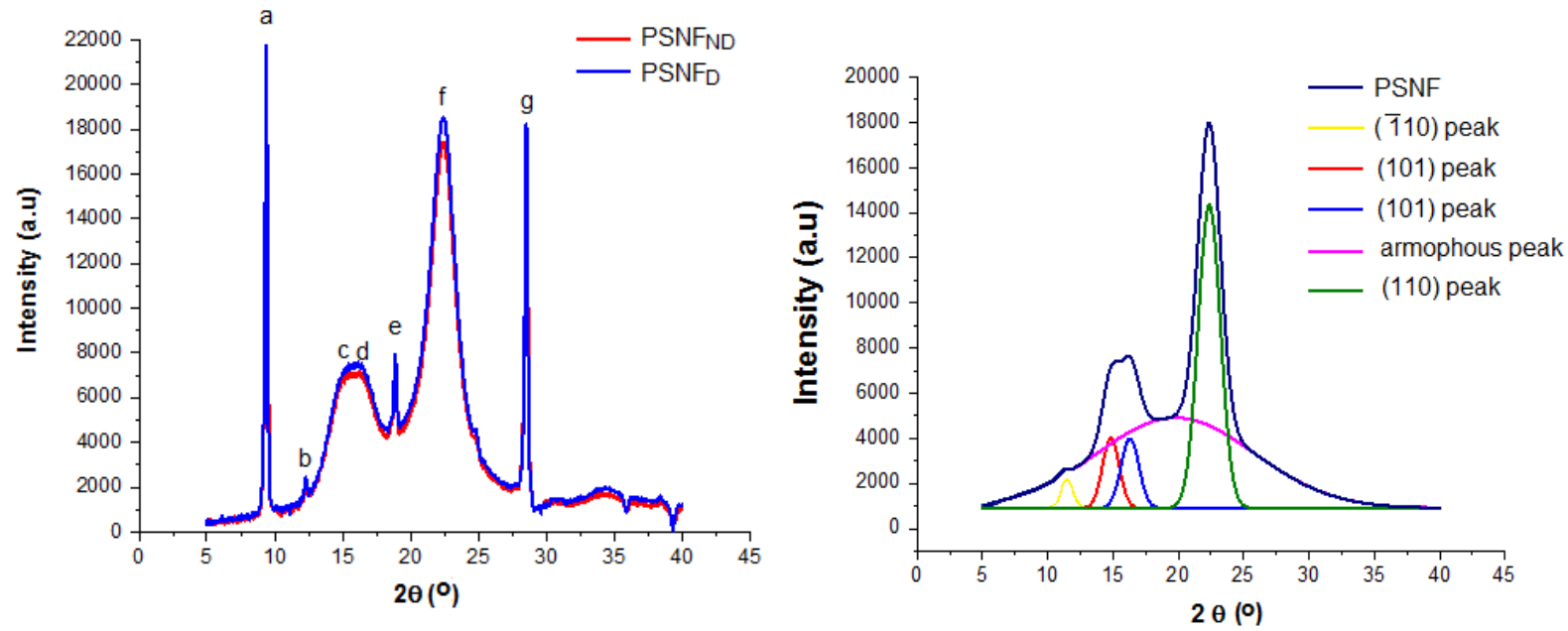

Fig.6. X-ray diffraction patterns of nanopapers prepared from $\mathrm{PSNF}_{\mathrm{ND}}$ and $\mathrm{PSNF}_{\mathrm{D}}$ highlighting crystalline peaks from talc (left) and X-ray diffraction pattern of PSNF nanopaper after peak fitting (right)

Fig. 6 (right) shows the deconvolution of cellulose intensities used to calculate the $\mathrm{CrI}$. The intensity (110) at $12.8^{\circ}$ is indicative of a cellulose II structure. The (101) intensity at an angle $14.8^{\circ}$ and $16.8^{\circ}$ respectively are related to intermolecular hydrogen bonds. Both PSNF show an intensity (110) at an angle $22.5^{\circ}$ which is characteristic of a cellulose I structure; this becomes a double peak around $20.6^{\circ}$ if regeneration occurs and the cellulose structure changes to cellulose II (Sharma et al., 2015). A broad peak at $20.6^{\circ}$ was chosen for the amorphous region. The CrIs for $\mathrm{PSNF}_{\mathrm{ND}}$ and $\mathrm{PSNF}_{\mathrm{D}}$ were calculated as $69 \%$ and $67 \%$, based on Segal's method, whereas the peak fitting method resulted in CrIs of $43 \%$ and $46 \%$ respectively. 


\subsection{Optical properties of paper sludge nanofibres}

Nanopaper exhibits excellent transmittance properties depending on how small the nanofibre diameters are, in comparison to the wavelength of visible light. Additionally, if the CNFs are densely packed, air scattering can be supressed thereby improving the transparency of the material. Fig.7. shows the transmittance spectrum of $0.2 \mathrm{wt}$.\% suspension of PSNF. Both nanopapers prepared from never-dried and dried PSNF showed a low visible light transmittance of 32.4\% (at $600 \mathrm{~nm}$ wavelength). CNFs has shown up to $90 \%$ transmittance in other studies making materials suitable for applications in electronic devices (Alila et al., 2013; Isogai et al., 2011; Nogi et al., 2009). Nevertheless, the PSNF nanopapers exhibit $15.8 \%$ transmittance of UV light at $300 \mathrm{~nm}$, which is a desirable property for UV absorption in packaging applications. This low UV transmittance has been previously noted by other work on nanopapers made from bacterial cellulose impregnated with gelatin (Quero et al., 2015). Hot pressing the PSNF suspension into nanopaper increases the transparency of the sheet as shown in Figure 7; the opacity test resulted in $44 \pm 0.3 \%$. The increased transparency is due to capillary action during water evaporation from the sheets causing the fibres to be densely packed together allowing more light to pass through the sheets. In addition the surface roughness is also reduced (Nogi et al., 2013).
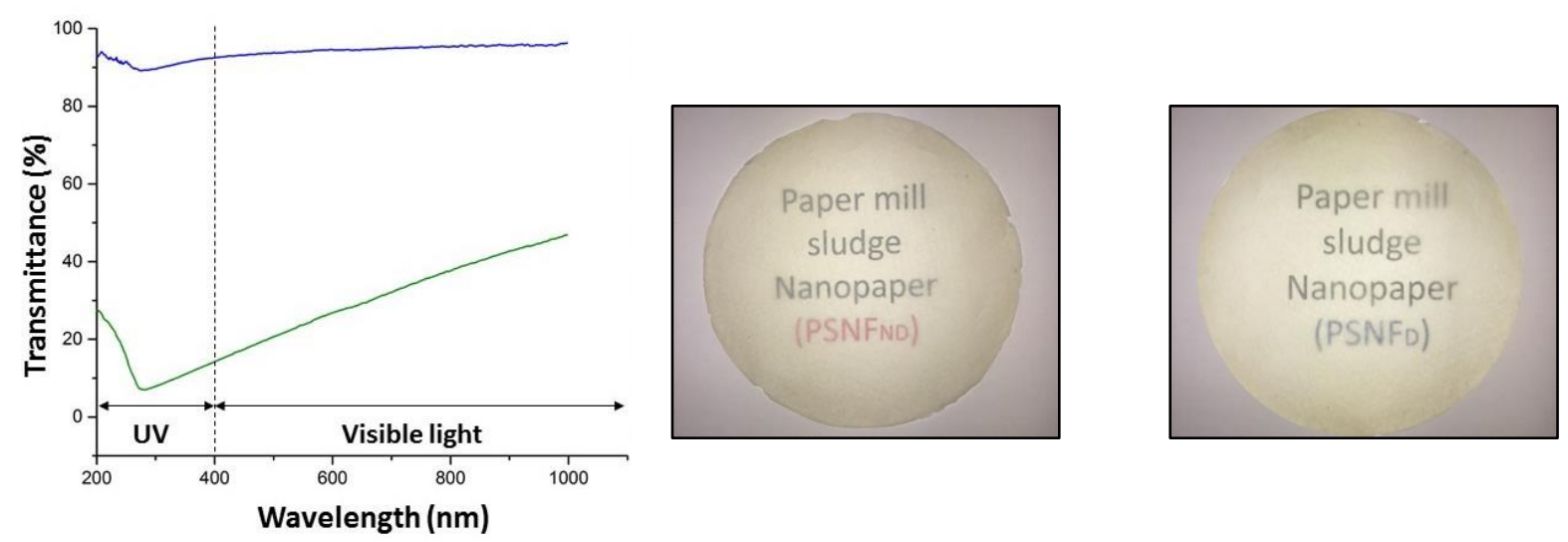

Fig.7. (From left) Typical light transmittance spectra of PSNF suspension (green line) with water (blue line) for reference, and typical images of nanopaper prepared from $\mathrm{PSNF}_{\mathrm{ND}}$ and $\mathrm{PSNF}_{\mathrm{D}}$

\subsection{Mechanical properties of paper sludge nanofibres network}

PSNF samples were collected at different time intervals and prepared into sheets for tensile tests as shown in Fig 8. All samples exhibited non-linear stress-strain curves typical for nanopaper sheets. An increase in the fibrillation time resulted in a proportional increase of tensile strength in the 
nanopaper sheets. $\mathrm{PSNF}_{\mathrm{ND}}$ showed double increases in tensile strength after 45 mins of fibrillation whereas the $\mathrm{PSNF}_{\mathrm{D}}$ increased slightly as larger fibres were still present. After 150 mins of fibrillation tensile strength values of $\sim 92 \mathrm{MPa}$ and $\sim 85 \mathrm{MPa}$ were ultimately achieved for dried and never-dried sludge. An increase in the mechanical properties of the cellulose paper is attributed to an increase in the amount of fibril-fibril bonding; this effect is thought to be due to an increased surface to volume ratio of the fibrils as they are processed.
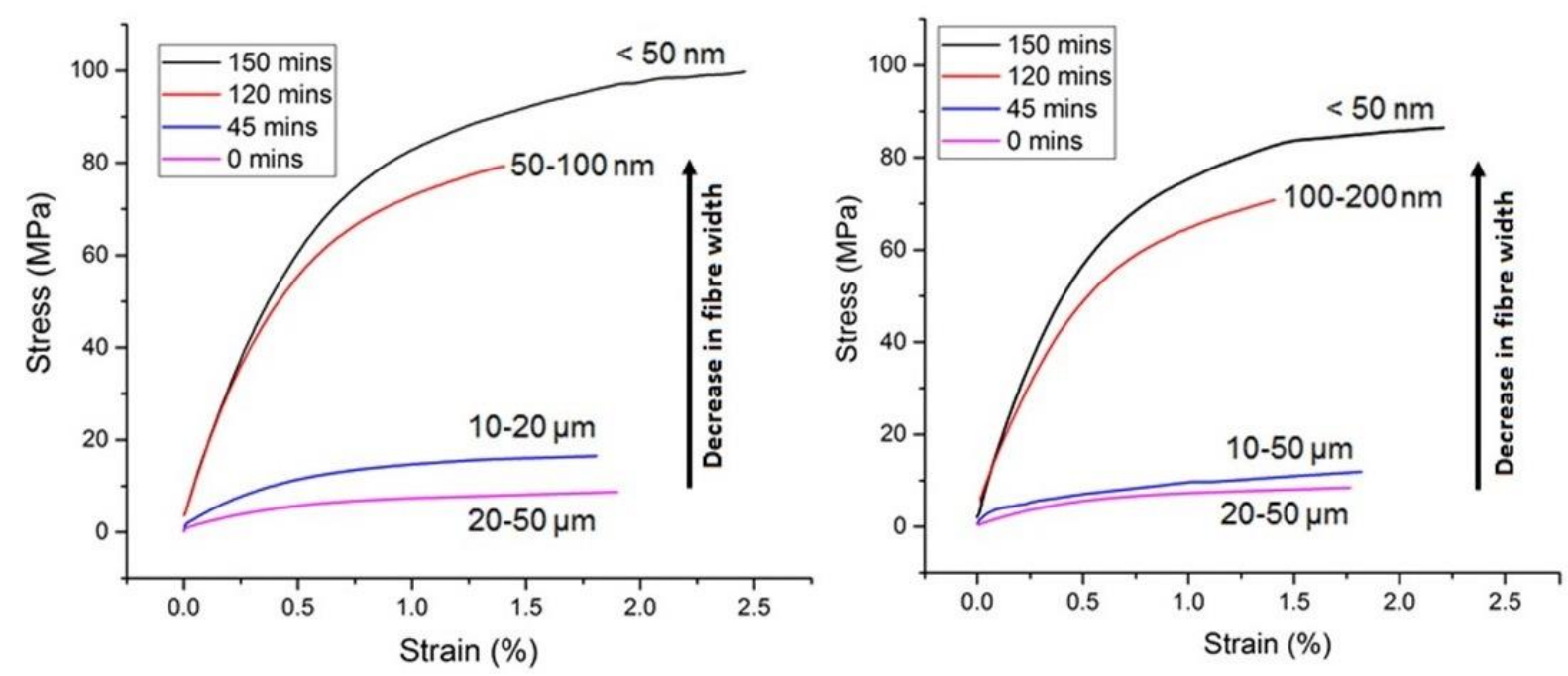

Fig. 8. Typical stress-strain curves of nanopapers produced from PSNFs collected at different fibrillation times showing the effect of a decrease in fibre/fibril width (from 20-50 $\mu \mathrm{m}$ to $<50 \mathrm{~nm}$ ) on tensile strength $\operatorname{PSNF}_{\mathrm{ND}}$ (left) and $\mathrm{PSNF}_{\mathrm{D}}$ (right).

Mechanical properties of paper sludge nanopapers were found to be similar to a previous study on nanocellulose derived from dissolving cellulose sludge (Jonoobi et al., 2012); data are shown in Table 2. Previous studies of cellulose nanopapers prepared from chemical treatment of wood pulp have reported values of $135 \mathrm{MPa}$ and $11 \mathrm{GPa}$ for tensile strength and elastic modulus (González et al., 2014). Additionally, different variations in the tensile modulus of cellulose nanopapers have been reported in the literature; values range between $9.4 \mathrm{GPa}$ to $14 \mathrm{GPa}$ (Henriksson et al., 2008; Lee et al., 2012; Quero et al., 2010).

\section{Table 2}


Average mechanical properties of paper mill sludge sheets

\begin{tabular}{lllll}
\hline & $\begin{array}{l}\text { Modulus } \\
\text { E [GPa] }\end{array}$ & $\begin{array}{l}\text { Tensile Strength } \\
{[\mathbf{M p a}]}\end{array}$ & $\begin{array}{l}\text { Tensile Strain } \\
{[\%]}\end{array}$ & $\begin{array}{l}\text { Tensile Index } \\
{[\mathbf{N m} / \mathbf{g}]}\end{array}$ \\
\hline PMS $_{\mathbf{N D}}$ & $1.7 \pm 0.3$ & $8.2 \pm 0.3$ & $1.8 \pm 0.1$ & $16.4 \pm 0.9$ \\
\hline PMS $_{\mathbf{D}}$ & $1.5 \pm 0.4$ & $7.9 \pm 0.2$ & $1.9 \pm 0.3$ & $14.3 \pm 0.7$ \\
\hline PSNF $_{\text {ND }}$ & $10.6 \pm 1.2$ & $91.5 \pm 8.8$ & $2.4 \pm 0.4$ & $71.9 \pm 5.6$ \\
\hline PSNF $_{\mathbf{D}}$ & $10.1 \pm 1.0$ & $85.4 \pm 10.2$ & $2.2 \pm 0.4$ & $71.5 \pm 5.6$ \\
\hline (Jonoobi et al., 2012) & $8.0 \pm 1.0$ & $96 \pm 4$ & $1.5 \pm 0.5$ & - \\
\hline
\end{tabular}

Figure 9 shows that the $\mathrm{PSNF}_{\mathrm{D}}$ exhibited mechanical properties comparable to $\mathrm{PSNF}_{\mathrm{ND}}$, the results show an 8-fold increase in the mechanical properties of nanopapers from raw sludge fibres to nanofibres. Based on the null hypothesis that there is no significant difference between the mechanical properties of the PSNF $\mathrm{ND}_{\text {and }}$ aSNF ${ }_{\mathrm{D}}$ samples. A Students T-test revealed P values of 0.32, 0.11, 0.85, 0.37 for tensile modulus, tensile strength, tensile index and tensile strain. The $(\mathrm{p}>0.05)$ indicated no statistical significant difference in the mechanical properties.
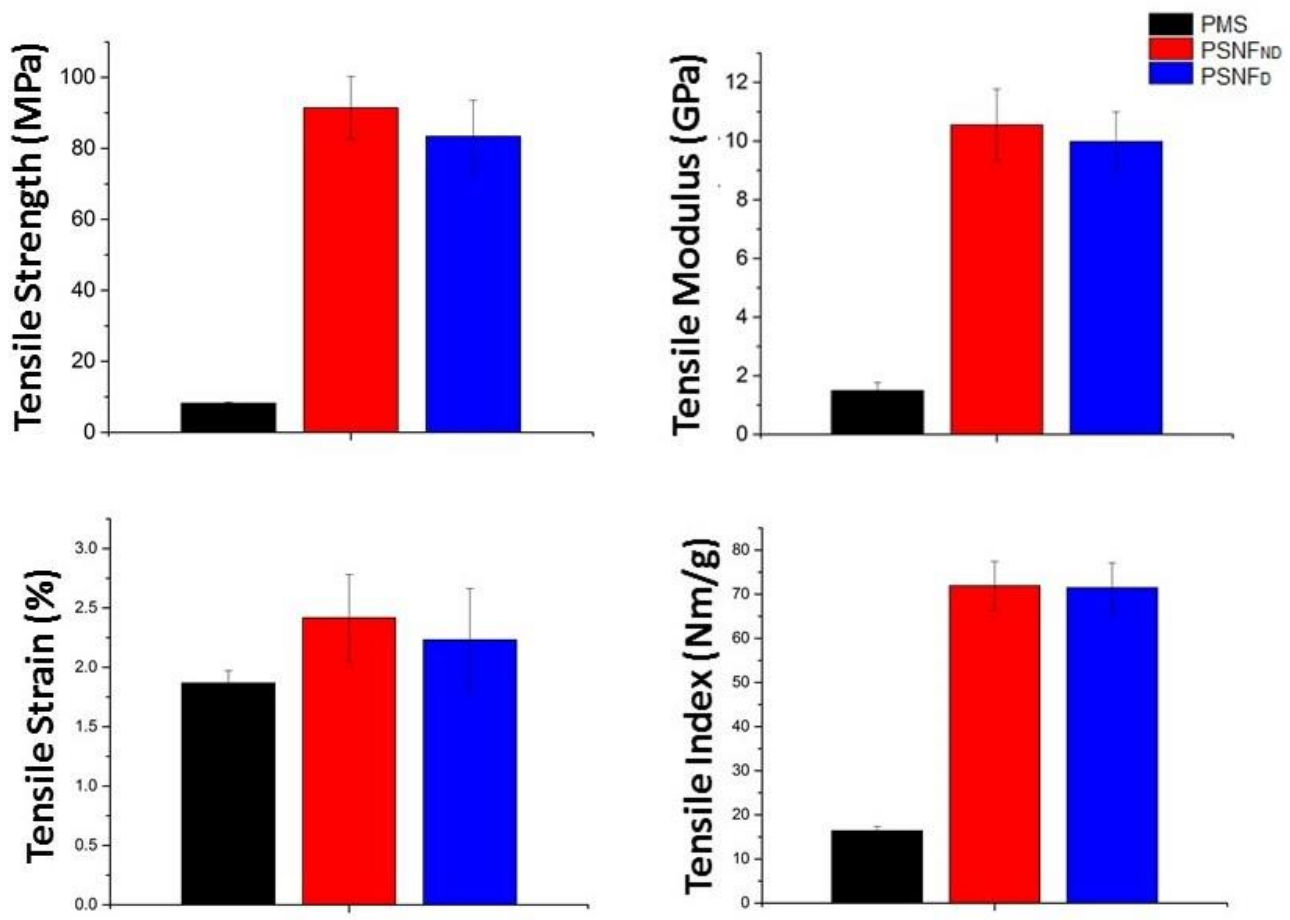

Fig.9. Mechanical properties of the nanopapers derived from paper mill sludge; tensile modulus, tensile strength, maximum strain and tensile index. 
The end-use price of CNF remains difficult to assess due to varying production methods influencing costs. The average selling price of CNF is estimated to range between $\$ 700-\$ 1200 /$ ton (Nechyporchuk et al., 2016). Moreover, market research has shown that the production of nanocellulose is currently valued at $\$ 65 \mathrm{M}$ with an annual growth rate of 30\% estimated to reach $\$ 530$ M by 2021 (Zion research analysis, 2016). Thus the 4000 tonnes of PMS produced annually at the mill has a potential revenue worth $\$ 2.8 \mathrm{M}$. Sludge can also be considered a free raw material which makes up for some of its production cost. A major barrier for the commercialisation success of CNF is the high energy cost required for mechanical disintegration. The energy consumption of the PMS fibrillation process was recorded as $30.6 \mathrm{MJ} / \mathrm{kg}(8.5 \mathrm{kWh} / \mathrm{kg})$ for never-dried sludge and $33.5 \mathrm{MJ} / \mathrm{kg}$ $(9.3 \mathrm{kwh} / \mathrm{kg})$ for dried sludge. These results are similar to fibrillating process of various wood pulps which averaged $36 \mathrm{MJ} / \mathrm{kg}(10 \mathrm{kWh} / \mathrm{kg}$ ) (Lahtinen et al., 2014). However, in comparison to a previous study of nanocellulose derived from dissolving pulp sludge, less energy was reported $4.68 \mathrm{MJ} / \mathrm{kg}(1.3$ $\mathrm{kWh} / \mathrm{kg}$ ) (Jonoobi et al., 2012). Nevertheless a higher energy consumption of $108 \mathrm{MJ} / \mathrm{kg}$ has also been reported for wood pulp fibrillated using a homogeniser (Eriksen et al., 2008). The cost for processing CNF from never-dried and dried sludge is $£ 425 /$ ton and $£ 465 /$ ton respectively based on average the UK wholesale electricity market price of $£ 50 / \mathrm{MWh}(1,000 \mathrm{kWh})(\mathrm{OFGEM}, 2018)$. The high water content in PMS up to 60\% largely determines transport and storage (Ochoa de Alda, 2008). The cost evaluation is shown in Table 3, where the cost of transportation is $0.53 \mathrm{f} / \mathrm{ton}-\mathrm{km}$ calculated based on a UK-based average heavy goods vehicle consumption of $15 \mathrm{mpg}$ (Department for Transport, 2016), a labour rate of $£ 10 / \mathrm{hr}$ and a fuel cost of $£ 1.10 /$ litre. The cost of storage was calculated based on an energy consumption of $180 \mathrm{kWh} /$ ton for cold storage and $360 \mathrm{kWh} / \mathrm{ton}$ for drying based on a specific energy consumption of $0.6 \mathrm{kWh} \mathrm{kg}^{-1} \mathrm{H}_{2} \mathrm{O}$ (Mäkelä et al., 2017).

\section{Table 3}

Cost evaluation of never-dried and dried PMS

\begin{tabular}{lll}
\hline & PMS $_{\mathbf{N D}}$ & PMS $_{\mathbf{D}}$ \\
\hline $\begin{array}{l}\text { Transport } \\
\text { (£/ton-km) }\end{array}$ & 1.33 & 0.53 \\
\hline $\begin{array}{l}\text { Storage } \\
\text { (£/ton) }\end{array}$ & 9 & 18 \\
\hline $\begin{array}{l}\text { Fibrillation } \\
\text { (£/ton) }\end{array}$ & 425 & 465 \\
\hline $\begin{array}{l}\text { Total Cost } \\
\text { (£/ton) }\end{array}$ & 435 & 483 \\
\hline
\end{tabular}




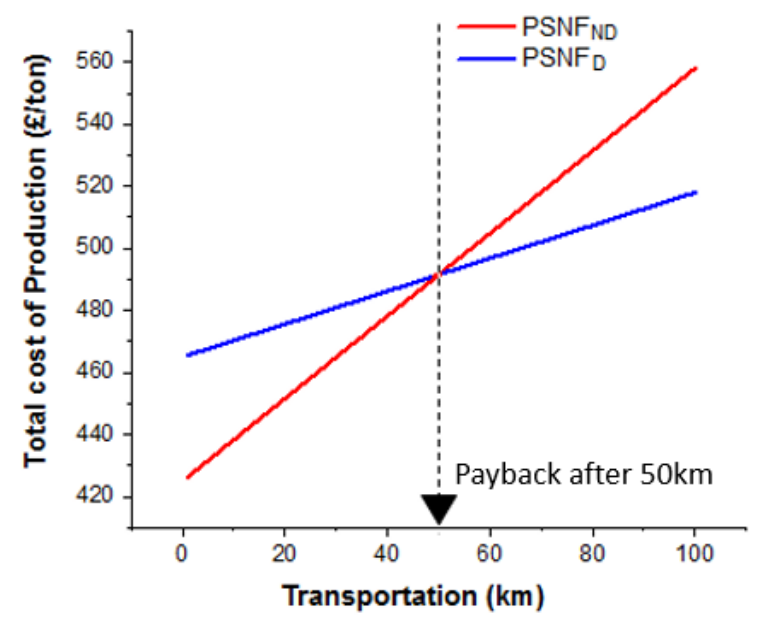

Fig.10. Payback evaluation for producing CNF from dried PMS in comparison with never-dried PMS To highlight the advantage of using dried PMS over never-dried PMS, the cost savings made during transportation of dried sludge must pay back the $£ 40 /$ ton increase when fibrillating dried PMS. The payback is calculated in Fig.10, by plotting the transport distance against total cost of producing PSNF from $\mathrm{PMS}_{\mathrm{ND}}$ and $\mathrm{PMS}_{\mathrm{D}}$. The evaluation revealed that the use of dried sludge for CNF production is favourable over never-dried sludge in situations when the sludge material is transported over $50 \mathrm{~km}$ from the mill for processing or kept in cold storage longer than 14 days.

\section{Conclusions}

A major limitation of industrial scale utilisation of biomass waste is in the transportation cost and microbial degradation. This study draws comparison between the production of CNF from dried and never-dried paper mill sludge which showed no significant difference in these materials in terms of their mechanical performance. Hence, dried sludge offers an economic advantage to alleviate challenges of microbial activity, storage and transportation, without compromising on the properties of the CNF. The nanopapers produced from both never-dried and dried PSNF showed high stiffness ( $\sim 11 \mathrm{GPa}$ and $\sim 10 \mathrm{GPa}$.) which could be used to improve mechanical properties of polymers limited by low mechanical strength such as polyvinyl alcohol (PVA). The low opacity (44\%) and low UV transmission of the PSNFs sheets also reveal potential application in the packaging field. Sludge obtained from various paper mills creates an opportunity for largescale valorisation to produce CNF with a free raw material. However, the variability in sludge composition from different mills poses a disadvantage in scaling up production. Thus, further investigation on the effect of the fillers contained in the sludge will provide more knowledge on developing a consistent product. 


\section{Acknowledgements}

The research was part-funded by the Engineering and Physics Research Science Council UK (Grant Number EP/L016389/1). The equipment used for the work were supported by funding from Bio4Energy Swedish strategic research program and Luleå University of Technology, Sweden. The authors would also like to thank Ecoganix LTD and the associated paper mill for providing sludge samples and data. 


\section{References}

Adu, C., Jolly, M., 2017. Developing Fiber and Mineral Based Composite Materials from Paper Manufacturing By-Products, in: Campana, G., Howlett, R.J., Setchi, R., Cimatti, B. (Eds.), Sustainable Design and Manufacturing 2017: Selected Papers on Sustainable Design and Manufacturing. Springer International Publishing, Cham, pp. 435-444. doi:10.1007/978-3-31957078-5_41

Alila, S., Besbes, I., Vilar, M.R., Mutjé, P., Boufi, S., 2013. Non-woody plants as raw materials for production of microfibrillated cellulose (MFC): A comparative study. Ind. Crops Prod. 41, 250259. doi:10.1016/j.indcrop.2012.04.028

Berglund, L., Noël, M., Aitomäki, Y., Öman, T., Oksman, K., 2016. Production potential of cellulose nanofibers from industrial residues : Efficiency and nanofiber characteristics 92, 84-92.

British Standards Institution BSI, 2008. BS ISO 2471:2008 Paper and board - Determination of opacity ( paper backing ) - Diffuse reflectance method.

Buzarovska, A., Bogoeva-Gaceva, G., Fajgar, R., 2016. Effect of the talc filler on structural, water vapor barrier and mechanical properties of poly(lactic acid) composites. J. Polym. Eng. 36, 181188. doi:10.1515/polyeng-2015-0014

Delgado-Aguilar, M., González, I., Tarrés, Q., Alcalà, M., Pèlach, M.À., Mutjé, P., 2015. Approaching a low-cost production of cellulose nanofibers for papermaking applications. BioResources 10, 5330-5344. doi:10.15376/biores.10.3.5330-5344

Department for Transport, 2016. Average heavy goods vehicle fuel consumption, Great Britain [WWW Document]. URL https://www.gov.uk/government/collections/energy-and-environmentstatistics

Eichhorn, S.J., Dufresne, A., Aranguren, M., Marcovich, N.E., Capadona, J.R., Rowan, S.J., Weder, C., Thielemans, W., Roman, M., Renneckar, S., Gindl, W., Veigel, S., Keckes, J., Yano, H., Abe, K., Nogi, M., Nakagaito, A.N., Mangalam, A., Simonsen, J., Benight, A.S., Bismarck, A., Berglund, L.A., Peijs, T., 2010. Review: current international research into cellulose nanofibres and nanocomposites, Journal of Materials Science. doi:10.1007/s10853-009-3874-0

Eriksen, Ø., Syverud, K., Gregersen, W.Ø., 2008. The use of microfibrillated cellulose produced from kraft pulp as strength enhancer in TMP paper. Nord. Pulp Pap. Res. J. 23, 299-304. doi:10.3183/NPPRJ-2008-23-03-p299-304

Faubert, P., Barnabé, S., Bouchard, S., Côté, R., Villeneuve, C., 2016. Pulp and paper mill sludge management practices: What are the challenges to assess the impacts on greenhouse gas emissions? Resour. Conserv. Recycl. 108, 107-133. doi:10.1016/j.resconrec.2016.01.007

Frías, M., Rodríguez, O., Sánchez de Rojas, M.I., 2015. Paper sludge, an environmentally sound alternative source of MK-based cementitious materials. A review. Constr. Build. Mater. 74, 37 48. doi:10.1016/j.conbuildmat.2014.10.007

García, O., Torres, A.L., Colom, J.F., Pastor, F.I.J., Díaz, P., Vidal, T., 2002. Effect of cellulaseassisted refining on the properties of dried and never-dried eucalyptus pulp. Cellulose 9, 115125. doi:10.1023/A:1020191622764

Ghribi, M., Meddeb-Mouelhi, F., Beauregard, M., 2016. Microbial diversity in various types of paper mill sludge: identification of enzyme activities with potential industrial applications. Springerplus 5. doi:10.1186/s40064-016-3147-8

Golbaghi, L., Khamforoush, M., Hatami, T., 2017. Carboxymethyl cellulose production from sugarcane bagasse with steam explosion pulping: Experimental, modeling, and optimization. Carbohydr. Polym. 174, 780-788. doi:10.1016/j.carbpol.2017.06.123 
González, I., Alcalà, M., Chinga-Carrasco, G., Vilaseca, F., Boufi, S., Mutjé, P., 2014. From paper to nanopaper: Evolution of mechanical and physical properties. Cellulose 21, 2599-2609. doi:10.1007/s10570-014-0341-0

Henriksson, M., Berglund, L.A., Isaksson, P., Lindstro, T., Nishino, T., 2008. Cellulose Nanopaper Structures of High Toughness Cellulose Nanopaper Structures of High Toughness 9, 15791585. doi:10.1021/bm800038n

Hsieh, Y.C., Yano, H., Nogi, M., Eichhorn, S.J., 2008. An estimation of the Young's modulus of bacterial cellulose filaments. Cellulose 15, 507-513. doi:10.1007/s10570-008-9206-8

Isogai, A., Saito, T., Fukuzumi, H., 2011. TEMPO-oxidized cellulose nanofibers. Nanoscale 3, 71-85. doi:10.1039/C0NR00583E

Jonoobi, M., Mathew, A.P., Oksman, K., 2012. Producing low-cost cellulose nanofiber from sludge as new source of raw materials. Ind. Crops Prod. 40, 232-238. doi:10.1016/j.indcrop.2012.03.018

Lahtinen, P., Liukkonen, S., Pere, J., Sneck, A., Kangas, H., 2014. A Comparative study of fibrillated fibers from different mechanical and chemical pulps. BioResources 9, 2115-2127. doi:10.15376/biores.9.2.2115-2127

Leão, A.L., Cherian, B.M., de Souza, S.F., Sain, M., Narine, S., Caldeira, M.S., Toledo, M.A.S., 2012. Use of Primary Sludge from Pulp and Paper Mills for Nanocomposites. Mol. Cryst. Liq. Cryst. 556, 254-263. doi:10.1080/15421406.2012.635974

Lee, K.Y., Tammelin, T., Schulfter, K., Kiiskinen, H., Samela, J., Bismarck, A., 2012. High performance cellulose nanocomposites: Comparing the reinforcing ability of bacterial cellulose and nanofibrillated cellulose. ACS Appl. Mater. Interfaces 4, 4078-4086. doi:10.1021/am300852a

Likon, M., Cernec, F., Svegl, F., Saarela, J., Zimmie, T.F., 2011. Papermill industrial waste as a sustainable source for high efficiency absorbent production. Waste Manag. 31, 1350-6. doi:10.1016/j.wasman.2011.01.012

Lin, Y., Ma, X., Ning, X., Yu, Z., 2015. TGA-FTIR analysis of co-combustion characteristics of paper sludge and oil-palm solid wastes. Energy Convers. Manag. 89, 727-734. doi:10.1016/j.enconman.2014.10.042

Mäkelä, M., Edler, J., Geladi, P., 2017. Low-temperature drying of industrial biosludge with simulated secondary heat. Appl. Therm. Eng. 116, 792-798. doi:10.1016/j.applthermaleng.2017.02.010

Monte, M.C., Fuente, E., Blanco, A., Negro, C., 2009. Waste management from pulp and paper production in the European Union. Waste Manag. 29, 293-308. doi:10.1016/j.wasman.2008.02.002

Moon, R.J., Martini, A., Nairn, J., Simonsen, J., Youngblood, J., 2011. Cellulose nanomaterials review: structure, properties and nanocomposites, Chem Soc Rev. doi:10.1039/c0cs00108b

Nechyporchuk, O., Belgacem, M.N., Bras, J., 2016. Production of cellulose nanofibrils: A review of recent advances. Ind. Crops Prod. 93, 2-25. doi:10.1016/j.indcrop.2016.02.016

Nogi, M., Iwamoto, S., Nakagaito, A.N., Yano, H., 2009. Optically Transparent Nanofiber Paper. Adv. Mater. 21, 1595-1598. doi:10.1002/adma.200803174

Nogi, M., Kim, C., Sugahara, T., Inui, T., Takahashi, T., 2013. High thermal stability of optical transparency in cellulose nanofiber paper High thermal stability of optical transparency in cellulose nanofiber paper. Appl. Phys. Lett. 102, 181911-4. doi:10.1063/1.4804361

Northolt, M.G., den Decker, P., Picken, S.J., Baltussen, J.J.M., Schlatmann, R., 2005. The Tensile Strength of Polymer Fibres, in: -/-, -/- (Ed.), Polymeric and Inorganic Fibers: -/-. Springer Berlin Heidelberg, Berlin, Heidelberg, pp. 1-108. doi:10.1007/b104207 
Nuruddin, M., Hosur, M., Uddin, M.J., Baah, D., Jeelani, S., 2016. A novel approach for extracting cellulose nanofibers from lignocellulosic biomass by ball milling combined with chemical treatment. J. Appl. Polym. Sci. 133, 1-10. doi:10.1002/app.42990

Ochoa de Alda, J.A.G., 2008. Feasibility of recycling pulp and paper mill sludge in the paper and board industries. Resour. Conserv. Recycl. 52, 965-972. doi:10.1016/j.resconrec.2008.02.005

OFGEM, 2018. Electricity prices: Day-ahead baseload contracts - monthly average (GB) [WWW Document]. URL https://www.ofgem.gov.uk/data-portal/electricity-prices-day-ahead-baseloadcontracts-monthly-average-gb

Oksman, K., Aitomäki, Y., Mathew, A.P., Siqueira, G., Zhou, Q., Butylina, S., Tanpichai, S., Zhou, X., Hooshmand, S., 2016. Review of the recent developments in cellulose nanocomposite processing. Compos. Part A Appl. Sci. Manuf. 83, 2-18. doi:10.1016/j.compositesa.2015.10.041

Park, S., Baker, J.O., Himmel, M.E., Parilla, P.A., Johnson, D.K., 2010. Cellulose crystallinity index: Measurement techniques and their impact on interpreting cellulase performance. Biotechnol. Biofuels 3, 1-10. doi:10.1186/1754-6834-3-10

Phillips, V.R., Kirkpatrick, N., Scotford, I.M., White, R.P., Burton, R.G.O., 1997. The use of papermill sludges on agricultural land. Bioresour. Technol. 60, 73-80. doi:10.1016/S09608524(97)00006-0

Pickering, K.L., Efendy, M.G.A., Le, T.M., 2015. A review of recent developments in natural fibre composites and their mechanical performance. Compos. Part A Appl. Sci. Manuf. 83, 98-112. doi:10.1016/j.compositesa.2015.08.038

Quero, F., Coveney, A., Lewandowska, A.E., Richardson, R.M., Díaz-Calderón, P., Lee, K.Y., Eichhorn, S.J., Alam, M.A., Enrione, J., 2015. Stress transfer quantification in gelatin-matrix natural composites with tunable optical properties. Biomacromolecules 16, 1784-1793. doi:10.1021/acs.biomac.5b00345

Quero, F., Nogi, M., Yano, H., Abdulsalami, K., Holmes, S.M., Sakakini, B.H., Eichhorn, S.J., 2010. Optimization of the mechanical performance of bacterial cellulose/poly(L-lactic) acid composites. ACS Appl. Mater. Interfaces 2, 321-330. doi:10.1021/am900817f

Sakurada, I., Nukushina, Y., T., I., 1962. Experimental determination of the elastic modulus of crystalline regions in oriented polymers. J. Polym. Sci. 57, 651-660. doi:10.1002/pol.1962.1205716551

Segal, L., Creely, J.J., Conrad, M., Martin, A.E., 1958. An Empirical Method for Estimating the Degree of Crystallinity of Native Cellulose Using the X-Ray Diffractometer. Text. Res. J. 786794.

Sharma, S., Nair, S.S., Zhang, Z., Ragauskas, A.J., Deng, Y., 2015. Characterization of micro fibrillation process of cellulose and mercerized cellulose pulp. RSC Adv. 5, 63111-63122. doi:10.1039/C5RA09068G

Spinu, M., Dos Santos, N., Le Moigne, N., Navard, P., 2011. How does the never-dried state influence the swelling and dissolution of cellulose fibres in aqueous solvent? Cellulose 18, 247-256. doi:10.1007/s10570-010-9485-8

Sturcova, A., Davies, G.R., Eichhorn, S.J., 2005. Elastic modulus and stress-transfer properties of tunicate cellulose whiskers. Biomacromolecules 2, 1055-1061. doi:doi: 10.1021/bm049291k

TAPPI, 2006. Tensile properties of paper and paperboard (using constant rate of elongation apparatus). T 494 om-01. TAPPI 1-28.

TAPPI, T., 2004. 211 om-02; Ash in wood, pulp, paper and paperboard: combustion at 525 C. TAPPI test methods 2005, 3-6.

Trache, D., Hussin, M.H., Haafiz, M.K.M., Thakur, V.K., 2017. Recent progress in cellulose 
nanocrystals: sources and production. Nanoscale 9, 1763-1786. doi:10.1039/C6NR09494E

Valentine, J., Clifton-Brown, J., Hastings, A., Robson, P., Allison, G., Smith, P., 2012. Food vs. fuel: The use of land for lignocellulosic "next generation" energy crops that minimize competition with primary food production. GCB Bioenergy 4, 1-19. doi:10.1111/j.1757-1707.2011.01111.x

Villagrá, A., Olivas, I., Benitez, V., Lainez, M., 2011. Evaluation of sludge from paper recycling as bedding material for broilers. Poult. Sci. 90, 953-957. doi:10.3382/ps.2010-00935

Yang, H., Yan, R., Chen, H., Zheng, C., Lee, D.H., Uni, V., V, N.D., March, R. V, Re, V., Recei, M., September, V., 2006. In-Depth Investigation of Biomass Pyrolysis Based on Three Major Components : Hemicellulose, Cellulose and Lignin 388-393.

Yousefi, H., Faezipour, M., Hedjazi, S., Mousavi, M.M., Azusa, Y., Heidari, A.H., 2013.

Comparative study of paper and nanopaper properties prepared from bacterial cellulose nanofibers and fibers/ground cellulose nanofibers of canola straw. Ind. Crops Prod. 43, 732-737. doi:10.1016/j.indcrop.2012.08.030 
2018-06-27

\title{
Properties of cellulose nanofibre
}

\section{networks prepared from never-dried and dried paper mill sludge}

\author{
Adu, Cynthia
}

Elsevier

Adu C, Berglund L, Oksman K, Eichhorn SJ, Jolly M, Zhu C, Properties of cellulose nanofibre networks prepared from never-dried and dried paper mill sludge, Journal of Cleaner Production, Volume 197, Part 1, 1 October 2018, pp. 765-771

http://dx.doi.org/10.1016/j.jclepro.2018.06.263

Downloaded from Cranfield Library Services E-Repository 